J. Dairy Sci. 96:4149-4159

http://dx.doi.org/10.3168/jds.2012-6263

(C) American Dairy Science Association ${ }^{\circledR}, 2013$. Open access under CC BY-NC-ND license.

\title{
Microbiological and chemical characteristics of Brazilian kefir during fermentation and storage processes
}

\author{
A. M. O. Leite, ${ }^{* 1}$ D. C. A. Leite,† E. M. Del Aguila, ${ }^{*}$ T. S. Alvares, ${ }^{*}$ R. S. Peixoto,† M. A. L. Miguel,‡ J. T. Silva, ${ }^{*}$ \\ and V. M. F. Paschoalin* \\ *Departamento de Bioquímica, Instituto de Química, \\ †Departamento de Microbiologia Geral, and \\ $\ddagger$ Departamento Microbiologia Médica, Instituto de Microbiologia Paulo de Góes, Universidade Federal do Rio de Janeiro, Rio de Janeiro, RJ, \\ Brazil
}

\begin{abstract}
The microbial community composition and chemical characteristics of a Brazilian milk kefir sample produced during its manufacturing and refrigerated storage were investigated by culture-dependent and -independent methods and HPLC. Lactococcus lactis ssp. cremoris and ssp. lactis, Leuconostoc mesenteroides, Acetobacter lovaniensis, and Saccharomyces cerevisiae were isolated, whereas the detected bands on denaturing gel gradient electrophoresis corresponded to Lactobacillus kefiranofaciens, Lactobacillus kefiri, Lactobacillus parakefiri, and S. cerevisiae. After fermentation, lactic acid bacteria were present at levels of $10 \log$ units, whereas acetic acid bacteria and yeast were present at levels of 7.8 and $6 \log$ units, respectively. The lactic acid bacteria and yeast counts remained constant, whereas acetic acid bacteria counts decreased to $7.2 \log$ units during storage. From fermentation to final storage, the $\mathrm{pH}$, lactose content and citric acid of the kefir beverage decreased, followed by an increase in the concentrations of glucose, galactose, ethanol, and lactic, acetic, butyric, and propionic acids. These microbiological and chemical characteristics contribute to the unique taste and aroma of kefir. This research may serve as a basis for the future industrial production of this beverage in Brazil.
\end{abstract}

Key words: microbial community, kefir, chemical composition, culture-dependent and culture-independent methods

\section{INTRODUCTION}

Kefir is a traditional dairy beverage originally from Caucasian and Eastern European regions, produced by the direct addition of kefir grains to milk. The bacteria

Received October 12, 2012.

Accepted March 8, 2013.

${ }^{1}$ Corresponding author: analyleite@yahoo.com.br and yeast that compose kefir grains are enclosed in a polysaccharide known as kefiran and a protein matrix. These microorganisms are responsible for the acid-alcoholic fermentation of the milk, producing a fermented milk product with unique properties. This product also has a long history of beneficial health effects, which has contributed significantly to the increase in the consumption of kefir and interest in this product in several Western countries (Farnworth and Mainville, 2008; Tamime et al., 2011).

The complex symbiotic relationship that exists among the microorganisms that compose the kefir grains makes them difficult to study, and also promotes relative stability and specificity of the kefir microbial community, which is generally composed of different lactic acid bacteria (LAB), acetic acid bacteria (AAB), and yeast species (Farnworth, 2005). However, some factors, such as the ratio of grain to milk, incubation, agitation, and storage conditions can influence the microbiological and chemical characteristics of the final kefir product (Farnworth, 2005; Irigoyen et al., 2005; Öner et al., 2010).

After milk fermentation with grains or commercial starter cultures, lactic acid, acetic acid, $\mathrm{CO}_{2}$, ethanol, and aromatic compounds are formed (Güzel-Seydim et al., 2000a; Grønnevik et al., 2011; Magalhães et al., $2011 a, b)$. The exotic aroma and flavor of kefir, a refreshing feature, and slightly acidic taste are the result of the coexistence of yeast and LAB in a symbiotic association, and depend on the diversity of the microbiota of each kefir grain (Güzel-Seydim et al., 2000a; Öner et al., 2010; Magalhães et al., 2011b; Leite et al., 2012).

Complex relationships between microbial communities are observed in different foods, especially in fermented foods, such as kefir (Garrote et al., 2010, Plessas et al., 2011).The relationship between microbial groups depends on biotic and abiotic factors and, thus, is characteristic of each manufacturing process. Although previous information exists regarding the microbiological diversity of kefir grains from different 
origins (Chen et al., 2008; Zhou et al., 2009; da Cruz Pedrozo Miguel et al., 2010; Leite et al., 2012) and of the final product (kefir beverage; Simova et al., 2002; Mainville et al., 2006; Magalhães et al., 2010b) using culture-dependent and -independent methods, few studies have been published with regard to monitoring of the microbial succession during milk fermentation by the traditional kefir grain (Guzel-Seydim et al., 2005; Magalhães et al., 2011b), as well as during storage of the final product (Irigoyen et al., 2005; Öner et al., 2010).

The commercial product kefir is not available in Brazil and, therefore, kefir grains are traditionally used as starters in the production of homemade kefir for personal consumption. Recently, some reports concerning mainly the chemical characterization of a Brazilian milk kefir have been described, although only during the fermentation process (Magalhães et al., 2011a,b), not evaluating the product during storage. The aim of this study was to evaluate the microbiological and chemical changes that occur not only in the different fermentation stages in kefir manufacturing but also during storage. For this purpose, samples were analyzed by traditional plating, isolation of microorganisms, and direct DNA and RNA extraction, followed by amplification [PCR and reverse-transcription PCR (RT-PCR)] of bacterial $16 \mathrm{~S}$ rRNA and yeast $26 \mathrm{~S}$ rRNA genes and denaturing gel gradient electrophoresis (DGGE) analysis. Organic acid concentration, ethanol production, and carbohydrate concentration at these different stages were also determined. Additionally, strains of $\mathrm{LAB}, \mathrm{AAB}$, and yeast were isolated and subsequently identified by DNA sequencing.

\section{MATERIALS AND METHODS}

\section{Kefir Grains}

Brazilian kefir grains (which we named AR grain) were obtained from a private household in Niterói (located in the state of Rio de Janeiro, Brazil) and had been previously characterized microbiologically by Leite et al. (2012). Grains were activated in sterile reconstituted skim milk $(10 \% \mathrm{wt} / \mathrm{vol})$ at $25^{\circ} \mathrm{C}$ for 24 $\mathrm{h}$, filtered to remove the clotted milk, and rinsed with sterile water. The activation step was repeated 3 times (Chen et al., 2008).

\section{Kefir Production}

The activated grains (30 g) were inoculated in commercial UHT skim milk $(1,000 \mathrm{~mL})$ and statically incubated at $25^{\circ} \mathrm{C}$ for $24 \mathrm{~h}$. Samples $(1 \mathrm{~mL})$ of the beverage were aseptically taken every $6 \mathrm{~h}$. Triplicate fermentations were performed. After $24 \mathrm{~h}$ of fermentation, sieved kefir samples (1-mm sieve size) were stored at $4 \pm 2^{\circ} \mathrm{C}$ and collected after $2,7,14$, and $28 \mathrm{~d}$ of refrigerated storage.

\section{Microbiological Analyses}

The enumeration of microorganisms from fermented milk was carried out by plating serial dilutions in sodium citrate $(2 \%)$ on different culture media, in triplicate. Lactic acid bacteria were enumerated on lactobacilli de Man, Rogosa, and Sharpe (MRS) agar (Difco; BD Diagnostics, Sparks, MD) and on M17 agar (Difco; BD Diagnostics) supplemented with $0.5 \%$ glucose (Difco; BD Diagnostics). Acetic acid bacteria were enumerated on AAB medium (Carr and Passmore, 1979). All media for bacterial enumeration were supplemented with 200 $\mathrm{mg} / \mathrm{kg}$ of cycloheximide (Sigma-Aldrich, St. Louis, MO) to inhibit yeast and fungi growth. Yeasts were enumerated on yeast extract-glucose-chloramphenicol agar (YGC; Difco; BD Diagnostics). Plates were incubated at $30^{\circ} \mathrm{C}$ for $5 \mathrm{~d}$ for bacterial growth under anaerobic conditions using a GasPak EZ anaerobic system (Difco; BD Diagnostics) and for yeast growth under aerobic conditions at $25^{\circ} \mathrm{C}$ for $5 \mathrm{~d}$. After counting, means and standard deviations were calculated.

To confirm the identity of the enumerated colonies, some isolates were taken at random from the agar plates for identification. Gram staining and catalase testing were used to screen the isolate strains as belonging to the $\mathrm{LAB}$ and $\mathrm{AAB}$ group and the samples were then analyzed by molecular methods. All isolated strains were stored in MRS broth with $20 \%$ glycerol at $-80^{\circ} \mathrm{C}$ until subsequent analyses.

\section{Amplified Ribosomal DNA Restriction Analysis}

Deoxyribonucleic acid template preparation from the isolated pure bacteria or yeast cultures was performed by the methods described by Randazzo et al. (2002) and Del Aguila et al. (2003), respectively. Polymerase chain reaction primers $27 \mathrm{f}$ (5'-AGAGTTTGATCCTGGCTCAG-3') and 1512r (5'-CGGCTACCTTGTTACGACT-3') were used to amplify the $16 \mathrm{~S}$ rRNA gene sequence, whereas primers ITS1 (5'-TCCGTAGGTGAACCTGCGG-3') and ITS4 (5'-TCCTCCGCTTATTGATATGC-3') were used to amplify internal transcribed spacer (ITS) regions, as described by Wang et al. (2006) and Naumova et al. (2005) for bacteria and fungi, respectively. Polymerase chain reaction products were then separated by electrophoresis on 1\% agarose gels. Amplicon bands were extracted and purified using the Illustra GFX PCR DNA and Gel Band Purification Kit (GE Healthcare Life Sciences, 
Uppsala, Sweden), according to the manufacturer's instructions. Ten microliters of purified amplicons was digested with the following restriction enzymes: FastDigest HaeIII and HhaI for LAB, FastDigest AluI and $S c r F 1$ for $\mathrm{AAB}$, and FastDigest $H h a \mathrm{I}$ and DdeI for yeast, as recommended by the manufacturer (Fermentas Inc., Glen Burnie, MD). Electrophoresis runs were then conducted in agarose gels $(1.5 \%)$ for $1 \mathrm{~h}$ and 45 min at $75 \mathrm{~V}$. Gels were stained with GelRed (Biotium Inc., Hayward, CA) diluted at 1:10,000 and visualized under UV light (data not shown).

Representative profiles of each species observed in the amplified ribosomal DNA restriction analysis were selected for sequencing. The sequencing analysis of partial 16S rRNA gene and ITS region was accomplished with a 3130 sequencer (Applied Biosystems Inc., Carlsbad, $\mathrm{CA}$ ) and subsequently used for identification to the species level of the bacteria and yeast isolates. The identity of the sequences was determined by using the BLASTN algorithm at the GenBank database (http://blast.ncbi. nlm.nih.gov/Blast.cgi?PROGRAM=blastn\&BLAST PROGRAMS = megaBlast\&PAGE_TYPE $=$ Blast Search).

\section{DNA and RNA Extraction of Kefir Beverage and Kefir Grains}

Kefir samples collected during fermentation and storage were stored at $-80^{\circ} \mathrm{C}$. Grain samples $(1 \mathrm{~g})$ used as inoculums were also collected and homogenized in $2 \%$ sodium citrate. One milliliter of each homogenate and $1 \mathrm{~mL}$ of kefir samples were then centrifuged for $10 \mathrm{~min}$ at $10,000 \times g$.

Genomic DNA was extracted and purified from the pellets using the FastDNA Spin kit (Qbiogene Inc., Carlsbad, CA) according to the manufacturer's instructions. Total RNA was extracted from the pellets in screw-cap tubes containing $0.3 \mathrm{~g}$ of glass beads and $1 \mathrm{~mL}$ of TRIzol reagent (Invitrogen Corp., Carlsbad, CA). Subsequently, two 40-s treatments at the maximum speed, with an interval of $1 \mathrm{~min}$ in an ice bath, were performed in a FastPrep instrument (Bio 101 Inc., Vista, CA). Tubes were then centrifuged at $12,000 \times g$ for $10 \mathrm{~min}$ at $4^{\circ} \mathrm{C}$, and $200 \mu \mathrm{L}$ of chloroform was added to supernatant. The tubes were centrifuged again at $12,000 \times g$ for 10 min at $4^{\circ} \mathrm{C}$ and the aqueous phase was precipitated with $1 \mathrm{~mL}$ of ice-cold absolute ethanol.

Ribonucleic acid was obtained after centrifugation at $14,000 \times g$ for $10 \mathrm{~min}$ at $4^{\circ} \mathrm{C}$, where the pellets were washed with $75 \%$ ethanol and dried at room temperature. Fifty microliters of sterile water was added, and a 30-min period at $45^{\circ} \mathrm{C}$ was used to facilitate nucleic acid solubilization. One microliter of DNase, RNase-free (Roche Diagnostics Corp., Indianapolis, IN) was added to digest the DNA at $37^{\circ} \mathrm{C}$ for $1 \mathrm{~h}$. The RNase solution was checked for the presence of residual amounts of DNA by performing PCR amplification. When positive signals were detected, the DNase treatment was repeated until the remaining DNA was eliminated.

\section{PCR and RT-PCR Protocol}

Bacterial DNA was used as the template for amplifications of the V3 region of the 16S rRNA gene using the universal primers F338-GC (5'-TACGGGAGGCAGCAG- ${ }^{\prime}$ ) and R518 (5'-ATTACCGCGGCTGCTGG-3'), as reported by Muyzer et al. (1993). The amplification of the D1 domain of the 26S rRNA gene of fungi was accomplished by using the primers NL1GC (5'-GCCATATCAATAAGCGGAGGAAAG-3') and LS2 (5'-ATTCCCAAACAACTCGACTC-3'), as reported by Cocolin et al. (2002). All GC primers contained a 39-bp GC clamp sequence at their $5^{\prime}$ end to prevent the complete denaturation of amplicons.

Reverse-transcription PCR was performed using the Ready-To-Go RT-PCR Beads kit (GE Healthcare Life Sciences), in which $1 \mu \mathrm{g}$ of total RNA was mixed with 25 pmol of each primer (338f-518r for bacteria and NL1-LS2 for yeasts), and the volume was brought up to $50 \mu \mathrm{L}$ with RNase-free (Invitrogen Corp.) sterile water. The reaction mixtures were incubated at $42^{\circ} \mathrm{C}$ for $20 \mathrm{~min}$ and after a $95^{\circ} \mathrm{C}$ incubation for $10 \mathrm{~min}$, the PCR conditions described by Muyzer et al. (1993) and Cocolin et al. (2002) were carried out for bacteria and yeast, respectively.

\section{DGGE Analysis of Kefir}

Denaturing gel gradient electrophoresis was performed using a DCode apparatus (Bio-Rad Laboratories Inc., Hercules, CA) at $60^{\circ} \mathrm{C}$ and using $8 \%$ polyacrylamide gels with a denaturing range of 30 to $55 \%$ for bacteria and 30 to $50 \%$ for fungi in $1 \times$ Tris-acetate-EDTA buffer at a constant voltage of $50 \mathrm{~V}$ for $10 \mathrm{~min}$, followed by $150 \mathrm{~V}$ for $4 \mathrm{~h}$ and $30 \mathrm{~min}$. After electrophoresis, the gels were stained with SYBR Green nucleic acid gel stain (1:10,000 dilution; Invitrogen Corp.) for $60 \mathrm{~min}$ and the DGGE band patterns were visualized under UV with the MiniBIS Pro gel imager (BioAmerica Inc., Miami, FL).

In addition, bands from the PCR-DGGE and RTPCR-DGGE gels were identified by nucleotide sequence analyses. For this purpose, the bands were excised from the acrylamide gels and processed by the Qiaex II DNA extraction kit (Qiagen GmbH, Hilden, Germany) according to the manufacturer's recommendations. The eluted DNA of each band was reamplified with the same primer pair without the GC clamp. Agarose gel 
electrophoresis of the PCR products was performed before purification and DNA was purified using the Illustra GFX PCR DNA and Gel Band Purification Kit (GE Healthcare Life Sciences) according to the manufacturer's instructions. Purified amplicons were directly ligated into the pGEM-T Easy Vector System (Promega Corp., Madison, WI) following the manufacturer's instructions. The ligation products were transformed into DH5a Escherichia coli competent cells. Positive clones (white colonies) were grown in LB agar containing ampicillin $(100 \mu \mathrm{g} / \mathrm{mL})$, isopropyl- $\beta$-D-1thiogalactopyranoside (IPTG; $0.5 \mathrm{mM}$ ), and 5-bromo4-chloro-3-indolyl- $\beta$-D-galactopyranoside (X-gal; $80 \mu \mathrm{g}$ / $\mathrm{mL}$ ). Plasmids were extracted using a minipreparation alkaline lyses method (Not et al., 2009). Sequencing of the insert was performed using a Big Dye Terminator system and an ABI 3730 automatic capillary sequencer (Applied Biosystems Inc.). The identity of sequences was determined by using the BLASTN algorithm at the GenBank database.

\section{HPLC Analysis}

Extraction of organic acids, ethanol, and carbohydrates from the kefir beverage was carried out as described by González de Llano et al. (1996). Briefly, 25 $\mathrm{mL}$ of $\mathrm{H}_{2} \mathrm{SO}_{4}(45 \mathrm{mmol} / \mathrm{L})$ was added to $5 \mathrm{~mL}$ of the kefir beverage and homogenized for $1 \mathrm{~h}$ in a rotatory shaker (Incubator 430; Nova Ética, São Paulo, Brazil) at $250 \mathrm{rpm}$. The supernatant fluid was then separated by centrifugation at $6,000 \times g$ and filtered through $0.45-\mu \mathrm{m}$ filters (Millipore Corp., Billerica, MA).

Filtered samples were injected $(50 \mu \mathrm{L})$ in triplicate into an HPLC system (Shimadzu Corp., Tokyo, Japan) equipped with an HPX-87H Aminex fermentation monitoring column $(150 \times 7.8-\mathrm{mm}$ i.d. $)$ and protected by a cation $\mathrm{H}^{+}$Micro-Guard cartridge $(30 \times 4.6-\mathrm{mm}$ i.d.; Bio-Rad Laboratories Inc.) maintained at $65^{\circ} \mathrm{C}$. Organic acids (lactic, acetic, citric, succinic, formic, butyric, and propionic acids) were quantified by using a diode array detector model SPD-M20A (Shimadzu Corp.) monitoring the absorbance at $210 \mathrm{~nm}$. Under these selected chromatographic conditions, we obtained the chromatogram of the standard mixture of all organic acids investigated in this study, shown in Figure 1. Carbohydrates and ethanol were quantified by using a refractive index detector model RID-10A (Shimadzu Corp.). The mobile phase (isocratic flow rate at 0.7 $\mathrm{mL} / \mathrm{min}$ ) used was $3 \mathrm{mM} \mathrm{H} \mathrm{H}_{2} \mathrm{SO}_{4}$. Chromatograms from HPLC and compound quantification were obtained using the LC Solution software (Shimadzu Corp.). Standard curves based on peak area were calculated for the individual organic acids, carbohydrates, and ethanol, covering a broad range of concentrations, by compari-

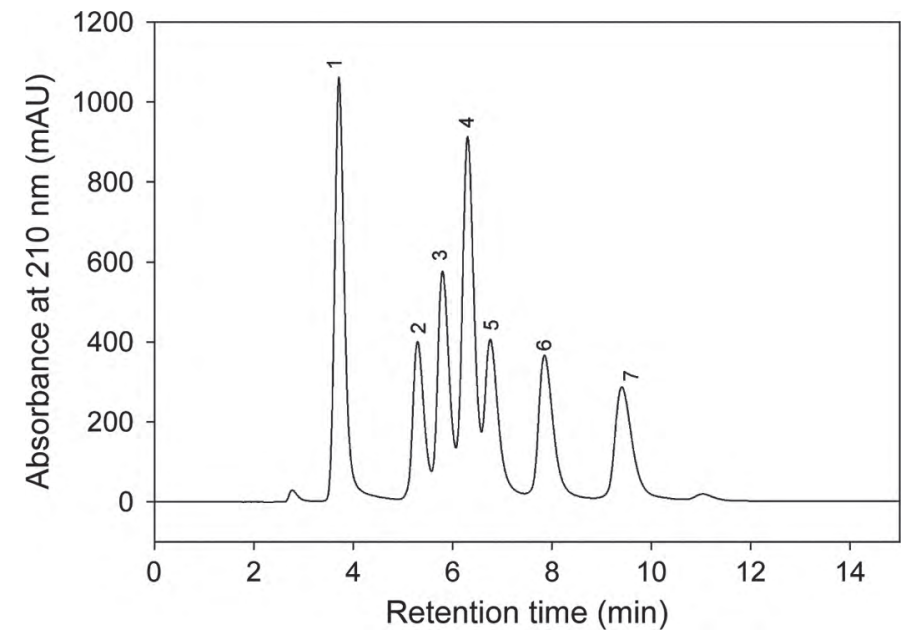

Figure 1. Chromatogram from HPLC of organic acid standards. Peaks: $1=$ citric acid, $2=$ succinic acid, $3=$ lactic acid, $4=$ formic acid, $5=$ acetic acid, $6=$ propionic acid, and $7=$ butyric acid.

son with standard solutions. Standards (Sigma-Aldrich) were prepared in deionized water filtered through $0.45-$ $\mu \mathrm{m}$ filters (Millipore Corp.).

\section{Statistical Analyses}

One-way ANOVA with repeated measures was used to identify differences between microbial enumerations, organic acids, carbohydrates, and ethanol content over the kefir beverages' fermentation and storage periods. When a significant F-value was found, additional post hoc tests with the Tukey adjustment were performed. Statistical significance was set at a 0.05 level of confidence. All analyses were performed using a commercially available statistical package (Statistica version 7.0; StatSoft Inc., Tulsa, OK).

Denaturing gel gradient electrophoresis patterns were normalized, compared, and clustered using the BioNumerics 6.5 software (Applied Maths NV, SintMartens-Latem, Belgium). Bands were automatically detected and matched, and further corrections were applied manually. Dendrograms relating band pattern similarities were automatically calculated with the Dice coefficient and unweighted pair group method with arithmetic mean (UPGMA).

\section{RESULTS}

\section{Microbial Enumeration During Kefir Beverage Fermentation and Storage}

Conventional microorganism enumeration was carried out during the 24-h milk fermentation (3\% kefir grain) at $25^{\circ} \mathrm{C}$ (Figure 2). Counts of presumptive LAB groups (M17 agar) increased $4 \mathrm{log}$ units at $12 \mathrm{~h}$ of fermentation 


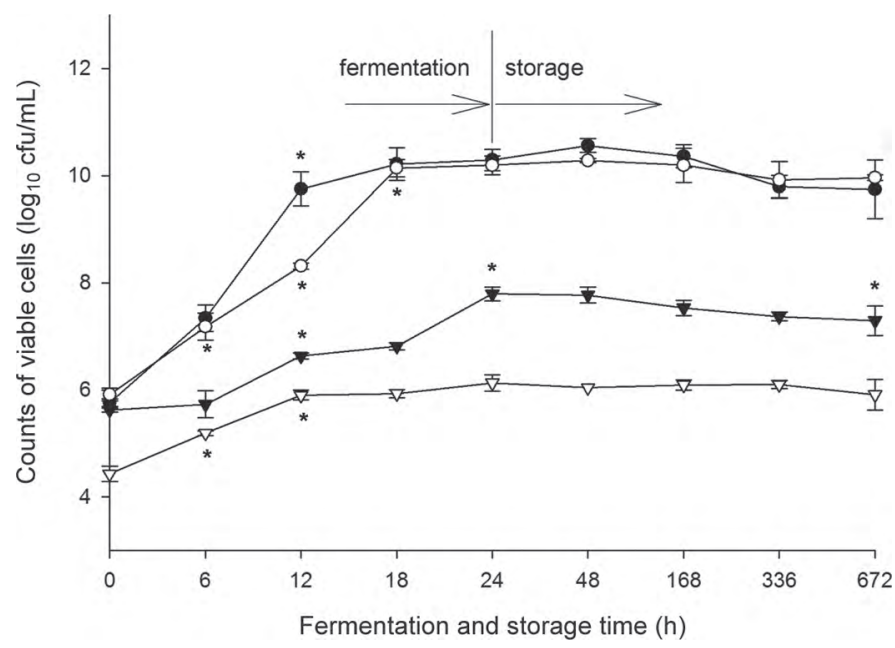

Figure 2. Microbial enumeration $\left(\log _{10} \mathrm{cfu} / \mathrm{mL}\right)$ of presumptive Lactobacillus spp. ( $\bigcirc)$ and Lactococcus spp. (๑) and presumptive acetic acid bacteria $(\mathbf{\nabla})$ and yeast $(\nabla)$ in Brazilian kefir beverage over the fermentation and storage periods (time $0=$ after grain inoculation). Data are the means of 3 runs of kefir beverage production; error bars show the standard deviations. ${ }^{*}$ indicates significant difference $(P<$ $0.05)$.

$(P<0.05)$, whereas counts on MRS agar at this same sampling point showed an increase of approximately $2 \log$ units, reaching maximum values (10 log units) within $18 \mathrm{~h}$ of fermentation. Presumptive AAB counts also increased significantly at $12 \mathrm{~h}$, reaching maximum values (7.8 log units) at $24 \mathrm{~h}$. Yeast counts increased until $12 \mathrm{~h}$, remaining constant at around $6 \mathrm{log}$ units over the fermentation period.

Microorganisms were also enumerated during kefir storage at $4^{\circ} \mathrm{C}$ for $672 \mathrm{~h}(28 \mathrm{~d}$; Figure 2). During this period, yeast (approximately $6 \mathrm{log}$ units) and LAB group counts (approximately $10 \mathrm{log}$ units) remained constant until the end of the storage period, whereas the count of presumptive $\mathrm{AAB}$ decreased to $7.2 \mathrm{log}$ units at $672 \mathrm{~h}$ of the storage period.

\section{Identification of Microbial Isolates}

To evaluate the diversity of the microbial isolates from the different growth media, distinct colonies were randomly selected at various stages within the fermentation and storage periods; 92 isolates were randomly selected from agar plates (M17, MRS, AAB, and YGC) and grouped into representative profiles obtained after amplified ribosomal DNA restriction analysis. Lactic acid bacteria strains showed 3 different representative profiles, whereas AAB and yeast strains showed only 1 . These isolates were identified by the sequence analysis of partial 16S rRNA gene and ITS region as the following: Leuconostoc mesenteroides (29\%), Lactococcus lactis ssp. lactis (5\%), Lactococcus lactis ssp. cremoris
(45\%), Acetobacter lovaniensis (10\%), and Saccharomyces cerevisiae (11\%), based on homology identity (98-100\%) searches at the GenBank database.

\section{Microbial Community Structure}

The microbial communities of Brazilian kefir were evaluated by DGGE using primer pairs $338-518$ and NL1-LS2 for the amplification of bacterial and yeast DNA and RNA sequences. Selected bands were excised (Figures 3 and 4) and sequenced after reamplification, followed by cloning and identification by sequence alignment according to the GenBank database (Table 1).

The cluster analysis for bacteria and yeast profiles allowed the identification of 2 main clusters, corresponding to the initial stages of fermentation and storage, with a coefficient of similarity between them of approximately 69 and $60 \%$ for bacteria and yeast, respectively. The DNA bacterial profiles from samples taken during the initial periods of fermentation $(0-18 \mathrm{~h})$ were grouped in one cluster (Figure 3A.1), with a coefficient of similarity of $75 \%$, whereas the second cluster (90\% similarity) comprised samples taken during the final fermentation period $(24 \mathrm{~h})$ and those analyzed during $672 \mathrm{~h}$ storage at $4^{\circ} \mathrm{C}$. The UHT skim milk and grain kefir samples were not grouped into these main clusters and showed a coefficient of similarity of 46 and $59 \%$, respectively.

The fingerprints of the yeast community (Figure 3A.2), at the initial fermentation periods (from 0 to 12 h) were shown to be identical and grouped in the same cluster as kefir grains, sharing a coefficient of similarity of $80 \%$. The second main cluster was comprised of kefir samples taken during the storage period (from 48 to $672 \mathrm{~h})$ and at the end of the fermentation period $(24 \mathrm{~h})$, exhibiting a coefficient of similarity of $72 \%$. The UHT skim milk showed only $32 \%$ of similarity with these 2 main clusters.

The DGGE profiles were similar when comparing DNA and RNA amplicons (Figures 3 and 4) and, consequently, the microorganisms identified after cloning and sequencing of the DGGE bands were also similar (Table 1). However, RNA band intensities were weaker than the ones obtained from DNA amplification. Concerning the RNA DGGE bacterial profiles (Figure 4), Lactobacillus kefiranofaciens was the predominant microorganism in both stages (fermentation and storage) and was identified by sequencing of bands $i, j, k$, and o (Figure 4A). Lactobacillus parakefiri (Figure 4A, band n) was identified in both the grain and kefir beverage during fermentation and storage, whereas Lactobacillus kefiri (Figure 4A, bands 1 and $\mathrm{m}$ ) was detected in the kefir grain, but not in the beverage.

Moreover, the yeast profile (Figure 4B) was much simpler than the bacterial DGGE fingerprints, as the 
A. 1

B.1

\section{$\%$ similarity}

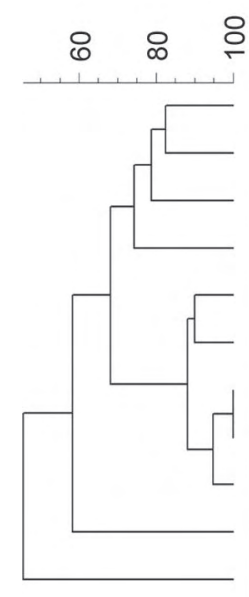

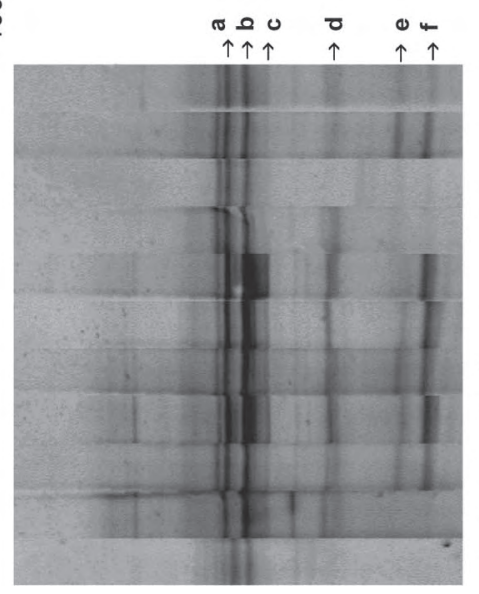

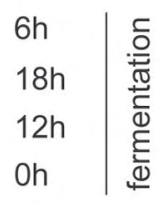

$168 \mathrm{~h}$

$672 \mathrm{~h}$

$48 \mathrm{~h}$

$336 \mathrm{~h}$

$24 \mathrm{~h}$

grain

milk
A. 2

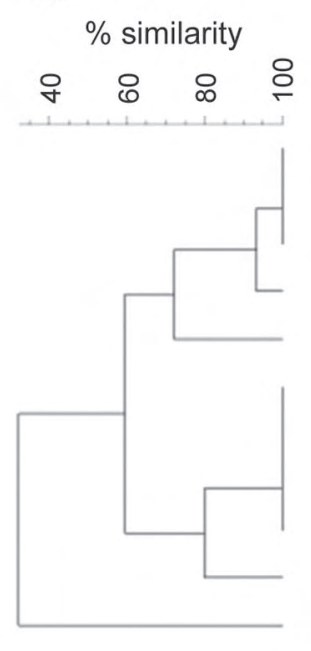

B.2

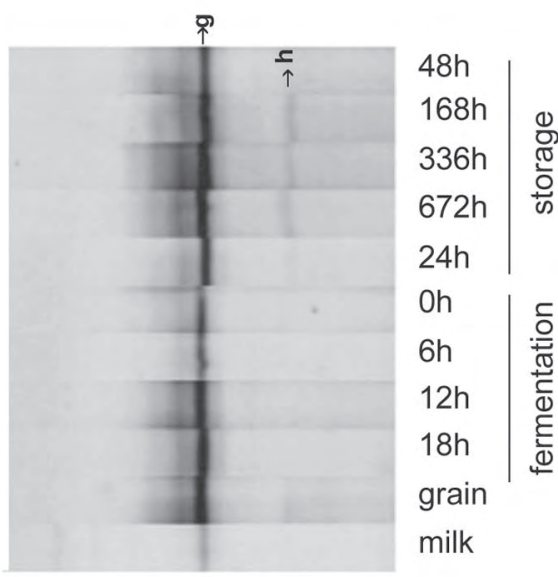

Figure 3. Polymerase chain reaction denaturing gel gradient electrophoresis (PCR-DGGE) profiles of the microbial community from milk, kefir grain, and kefir samples taken during Brazilian kefir manufacture and storage periods. Panel A: dendrograms generated by unweighted pair group method with arithmetic mean (UPGMA) clustering (Dice correlation coefficient) from bacteria DGGE (A.1) and yeast DGGE (A.2) profiles. The scale bar indicates the percentage of similarity. Panel B: DGGE profiles of the PCR products obtained from the V3 region of the $16 \mathrm{~S}$ rRNA gene for bacteria (B.1) and D1 region of the $26 \mathrm{~S}$ rRNA gene for yeasts (B.2). Bands: a $=$ Lactobacillus kefiranofaciens, b $=$ Lb. kefiranofaciens, $\mathrm{c}=$ Lb. kefiranofaciens, $\mathrm{d}=$ Lactobacillus kefiri, $\mathrm{e}=$ Lactobacillus parakefiri, $\mathrm{f}=$ Lb. kefiranofaciens, and $\mathrm{g}$ and $\mathrm{h}=$ Saccharomyces cerevisiae (yeasts).

yeast community presented only 2 bands, identified as Saccharomyces cerevisiae (Figure 4B, bands p and q). The UHT milk sample showed no amplification at the RNA level targeting $16 \mathrm{~S}$ and $26 \mathrm{~S}$ rRNA genes.

\section{HPLC Analysis of Metabolites During Kefir Beverage Fermentation and Storage}

When tracking the changes in carbohydrates, ethanol, and organic acids during fermentation and storage (Table 2), it was demonstrated that lactose content decreased after $12 \mathrm{~h}$ and remained low until $24 \mathrm{~h}$ of fermentation (from 43.4 to $32.4 \mathrm{mg} / \mathrm{mL}$ ), whereas during the storage period, a significant reduction only occurred at $28 \mathrm{~d}$, corresponding to $41 \%$ of the original milk content. Galactose and glucose levels showed a significant $(P<0.05)$ increase at $12 \mathrm{~h}$ of fermentation (from 0.18 to $0.29 \mathrm{mg} / \mathrm{mL}$ and 0.46 to $0.70 \mathrm{mg} / \mathrm{mL}$, respectively). After fermentation for $24 \mathrm{~h}$ until $14 \mathrm{~d}$ of storage, an increase was observed in galactose content (from 0.76 to $0.97 \mathrm{mg} / \mathrm{mL}$ ), whereas glucose content remained constant throughout the fermentation period, increasing at $2 \mathrm{~d}$ of storage (from 0.29 to $0.36 \mathrm{mg} / \mathrm{mL}$ ).

During the fermentation and storage periods, $\mathrm{pH}$ values (Table 2$)$ progressively decreased $(P<0.05)$, ranging from 6.55 to 4.31 , as a consequence of organic acid production. Lactic acid increased rapidly and significantly $(P<0.05)$ over the 24 -h fermentation period to $7.38 \mathrm{mg} / \mathrm{mL}$ and increased to $9.54 \mathrm{mg} / \mathrm{mL}$ at the final storage period $(28 \mathrm{~d})$. Acetic acid was also pro- duced at $12 \mathrm{~h}$ of the kefir fermentation process, reaching maximum values of 0.93 and $1.16 \mathrm{mg} / \mathrm{mL}$ after $24-\mathrm{h}$ fermentation and storage periods, respectively (Table 2 ). Succinic and formic acids were not detected during kefir fermentation.

Ethanol (Table 2) was produced after $18 \mathrm{~h}$ of fermentation $(0.14 \mathrm{mg} / \mathrm{mL})$ until $24 \mathrm{~h}$, when levels reached $0.32 \mathrm{mg} / \mathrm{mL}$. During storage, ethanol concentrations increased to $0.45 \mathrm{mg} / \mathrm{mL}$, reaching maximum values $(1.36 \mathrm{mg} / \mathrm{mL})$ at the $\mathrm{d} 28$ of storage.

The citrate (Table 2) present in the original milk decreased by more than $35 \%$ after $12 \mathrm{~h}$ of fermentation (from 4.29 to $2.73 \mathrm{mg} / \mathrm{mL}$ ), remaining constant until the end of the storage period, whereas propionic and butyric acids increased at 6 and $12 \mathrm{~h}$ of fermentation, respectively. A significant increase in the production of butyric acid during kefir fermentation $(24 \mathrm{~h})$ and storage $(2,7$, and $28 \mathrm{~d}$ ) was observed, whereas propionic acid increased at $12 \mathrm{~h}$ of fermentation (from 0.80 to $1.09 \mathrm{mg} / \mathrm{mL}$ ), remaining constant throughout the whole storage period, except for a significant decrease (to $0.96 \mathrm{mg} / \mathrm{mL} ; P<0.05$ ) at the d 28 of storage (Table $2)$.

\section{DISCUSSION}

Although kefir is a traditional beverage that has been consumed for many years in several countries, studies regarding the monitoring of chemical and microbiological changes during its fermentation process 
A

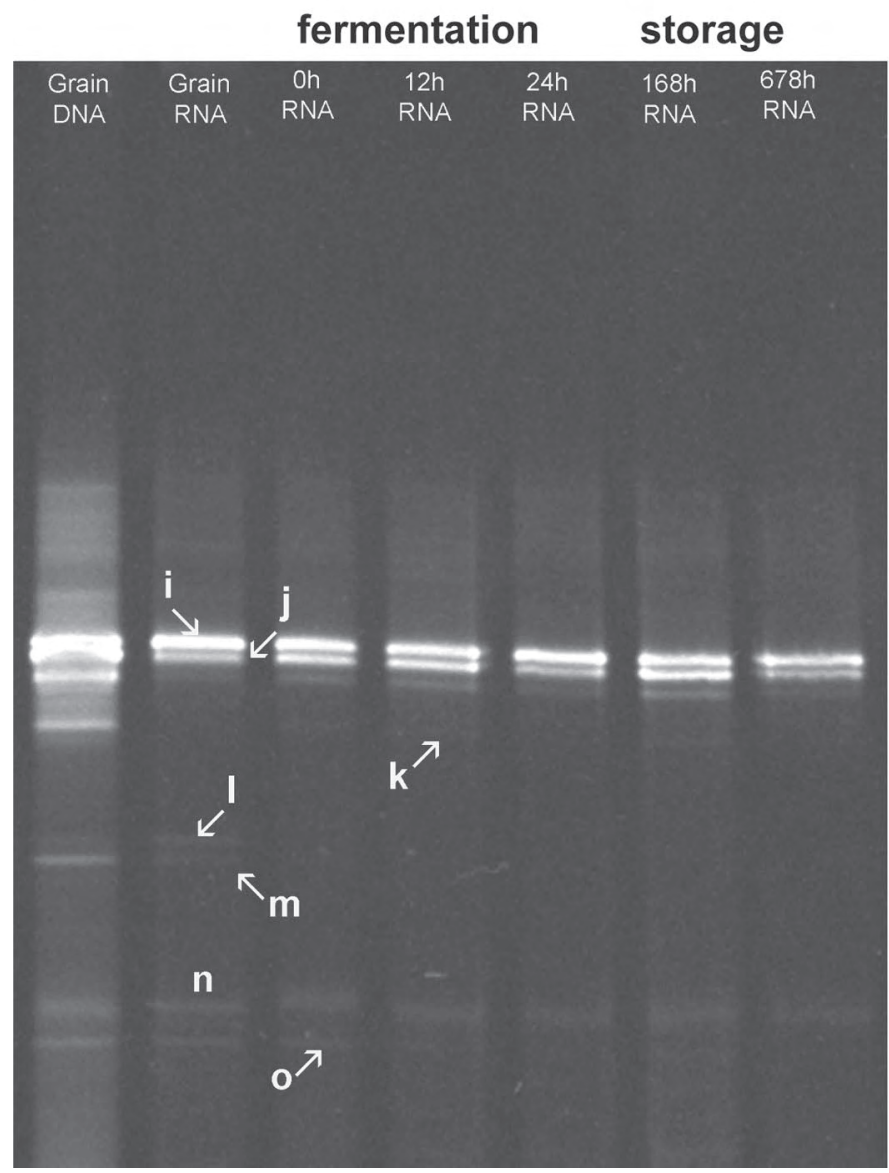

B

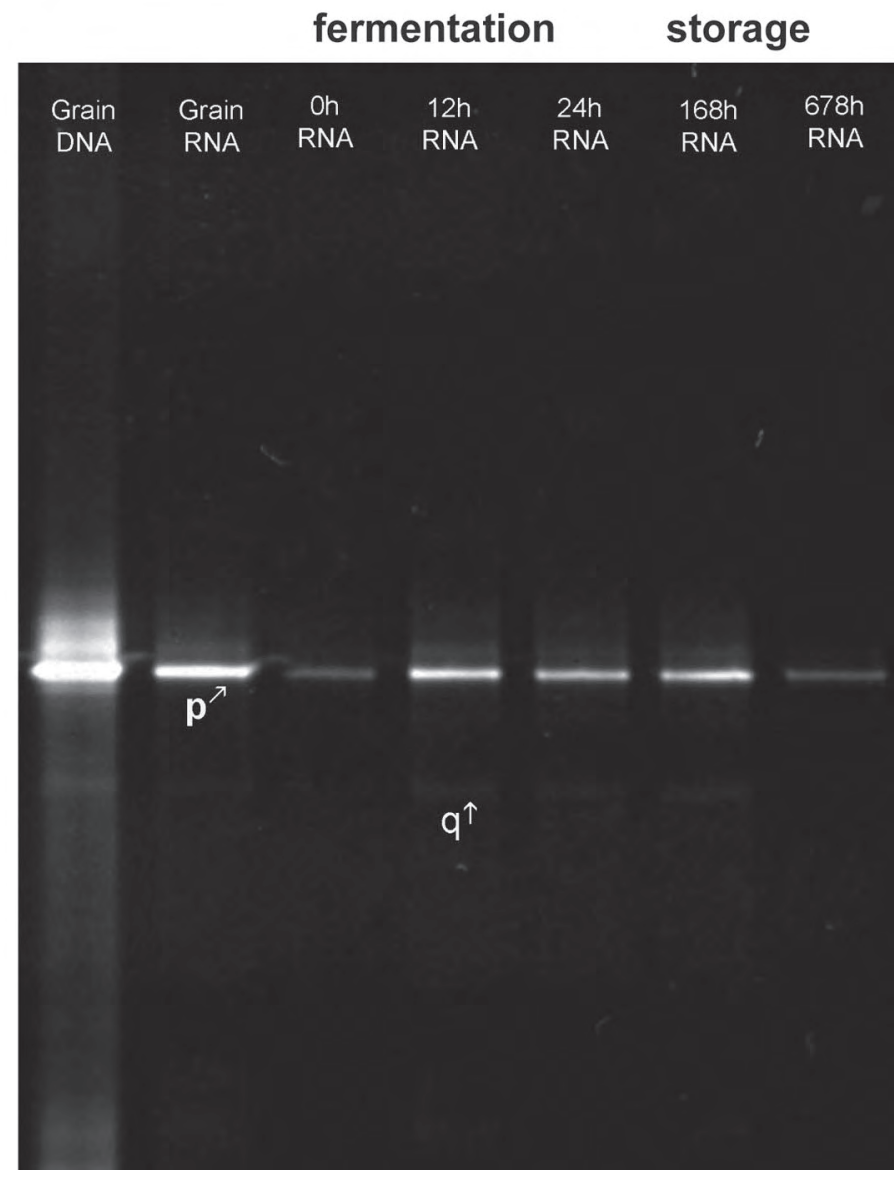

Figure 4. Polymerase chain reaction denaturing gel gradient electrophoresis (DGGE) DNA and reverse-transcription PCR-DGGE RNA profiles targeting the bacteria $16 \mathrm{~S}$ rRNA gene $(\mathrm{A})$ and yeast $26 \mathrm{~S}$ rRNA gene $(\mathrm{B})$ of kefir grain inoculum and samples of kefir beverage taken during fermentation and storage. Bands: $\mathrm{i}=$ Lactobacillus kefiranofaciens, $\mathrm{j}=$ Lb. kefiranofaciens, $\mathrm{k}=$ Lb. kefiranofaciens, $\mathrm{l}=$ Lactobacillus kefiri, $\mathrm{m}$ $=$ Lb. kefiri, $\mathrm{n}=$ Lactobacillus parakefiri, $\mathrm{o}=$ Lb. kefiranofaciens, and $\mathrm{p}$ and $\mathrm{q}=$ Saccharomyces cerevisiae (yeasts).

are scarce. It is required so that the product may be fully understood according to a scientific point of view. Thus, a polyphasic approach, using culture-dependent and culture-independent methods, was performed to investigate the dynamics of the microbial populations from a Brazilian kefir beverage sample.

In general, the results of traditional plating are in accordance with previous studies (Guzel-Seydim et al., 2005; García Fontán et al., 2006; Magalhães et al., 2011b), which reported a great increase in the microbial count during the first $24 \mathrm{~h}$ of kefir production. However, in the present study, the values at $24 \mathrm{~h}$ of fermentation were not similar to those published by other authors, most likely due to the kefir production conditions (Guzel-Seydim et al., 2005; García Fontán et al., 2006; Magalhães et al., 2011b) and the particular behavior of each grain. In the storage period, the results described in the present study corroborated those reported by
Öner et al. (2010) for kefir produced from cow milk, where the microorganism counts remained stable during the first $15 \mathrm{~d}$ of storage. However, Irigoyen et al. (2005) and Grønnevik et al. (2011) reported a significant decrease in the counts of presumptive lactobacilli and lactococci throughout $4 \mathrm{wk}$ of storage, whereas yeast and $\mathrm{AAB}$ counts remained constant in the findings described by Irigoyen et al. (2005). On the other hand, Grønnevik et al. (2011), showed a significant increase in yeast counts from Norwegian commercial kefir after 3 wk of storage. The microorganisms enumerated in the studied kefir beverage are in agreement with the specifications of FAO/WHO (2003), which recommend that kefir beverages should contain at least $10^{7}$ and $10^{4} \mathrm{cfu} / \mathrm{g}$ as minimum total bacteria and yeast counts, respectively, at the end of the storage period.

The analyses of bacteria and yeast communities by DGGE fingerprints showed no significant changes in 
Table 1. Identification of microorganisms in Brazilian kefir based on a BLAST comparison in the GenBank database (http://blast.ncbi.nlm.nih.gov/Blast.cgi) after cloning and sequencing of the selected bands from PCR and reverse-transcription PCR denaturing gel gradient electrophoresis, using universal primers for bacteria (16S rRNA gene) and yeasts (26S rRNA gene)

\begin{tabular}{llrl}
\hline Band & Closest sequence relative & \% Similarity & GenBank accession no. \\
\hline Bacteria & & & \\
$\mathrm{a}$ & Lactobacillus kefiranofaciens & 100 & CP002764.1/ AB372208.1 \\
$\mathrm{b}$ & Lb. kefiranofaciens & 100 & CP002764.1/AB372208.1 \\
$\mathrm{c}$ & Lb. kefiranofaciens & 100 & CP002764.1/AB372208.1 \\
$\mathrm{d}$ & Lactobacillus kefiri & 99 & AB429371.1/ FJ749410.1 \\
$\mathrm{e}$ & Lactobacillus parakefiri & 99 & AB370879.1/ NR_029039.1 \\
$\mathrm{f}$ & Lb. kefiranofaciens & 100 & CP002764.1/ AB372208.1 \\
$\mathrm{i}$ & Lb. kefiranofaciens & 100 & CP002764.1/ AB372208.1 \\
$\mathrm{j}$ & Lb. kefiranofaciens & 100 & CP002764.1/AB372208.1 \\
$\mathrm{k}$ & Lb. kefiranofaciens & 100 & CP002764.1/AB372208.1 \\
$\mathrm{l}$ & Lb. kefiri & 99 & AB429371.1/ FJ749410.1 \\
$\mathrm{m}$ & Lb. kefiri & 100 & AB429371.1/ FJ749410.1 \\
$\mathrm{n}$ & Lb. parakefiri & 100 & AB370879.1/ NR_029039.1 \\
$\mathrm{o}$ & Lb. kefiranofaciens & 100 & CP002764.1/ AB372208.1 \\
Yeasts & & & \\
$\mathrm{g}$ & Saccharomyces cerevisiae & 99 & EU441887.1/ BK006945.2 \\
$\mathrm{h}$ & S. cerevisiae & 100 & EU441887.1/ BK006945.2 \\
$\mathrm{p}$ & S. cerevisiae & 100 & EU441887.1/ BK006945.2 \\
$\mathrm{q}$ & S. cerevisiae & 100 & EU441887.1/ BK006945.2 \\
\hline
\end{tabular}

the community structures during kefir fermentation or storage, probably due to the existence of a dominant microbial consortium, corroborating the data reported by Magalhães et al. (2010b) that monitored the fermentation process of a sugary Brazilian kefir. For this reason, the RT-PCR-DGGE analysis was performed on certain sampling points, to evaluate the most predominant microorganisms in the active population at different stages of kefir fermentation and storage.
Several studies have performed analyses on reversetranscribed RNA to reveal population viability within the microbial community (Randazzo et al., 2002; Rantsiou et al., 2008; Dolci et al., 2010; Falentin et al., 2012), and some authors (Randazzo et al., 2002; Cocolin et al., 2004) have already been able to differentiate the active components (rRNA derived) from the total diversity (recombinant DNA derived) of the community, by combining RT-PCR-DGGE and PCR-DGGE. In

Table 2. Chemical compounds quantified by HPLC analysis during kefir manufacture and storage of kefir beverage at $4^{\circ} \mathrm{C}^{1}$

\begin{tabular}{|c|c|c|c|c|c|c|c|c|c|c|}
\hline \multirow{2}{*}{$\begin{array}{l}\text { Chemical } \\
\text { compound } \\
(\mathrm{mg} / \mathrm{mL})\end{array}$} & \multirow{2}{*}{$\begin{array}{l}\text { UHT } \\
\text { milk }\end{array}$} & \multicolumn{5}{|c|}{ Fermentation time $(\mathrm{h})$} & \multicolumn{4}{|c|}{ Storage time (d) } \\
\hline & & 0 & 6 & 12 & 18 & 24 & 2 & 7 & 14 & 28 \\
\hline Lactose & $\begin{array}{l}48.40 \\
(2.54)^{\mathrm{a}}\end{array}$ & $\begin{array}{l}46.30 \\
(1.47)^{\mathrm{ab}}\end{array}$ & $\begin{array}{l}45.80 \\
(0.95)^{\mathrm{ab}}\end{array}$ & $\begin{array}{l}43.40 \\
(0.28)^{\mathrm{b}}\end{array}$ & $\begin{array}{l}38.00 \\
(1.01)^{\mathrm{c}}\end{array}$ & $\begin{array}{l}32.40 \\
(0.79)^{\mathrm{d}}\end{array}$ & $\begin{array}{l}31.10 \\
(0.64)^{\text {de }}\end{array}$ & $\begin{array}{l}30.50 \\
(0.11)^{\mathrm{de}}\end{array}$ & $\begin{array}{l}30.30 \\
(0.73)^{\text {de }}\end{array}$ & $\begin{array}{l}28.40 \\
(1.22)^{\mathrm{e}}\end{array}$ \\
\hline Glucose & $\begin{array}{c}0.17 \\
(0.01)^{\mathrm{d}}\end{array}$ & $\begin{array}{l}0.18 \\
(0.01)^{\mathrm{d}}\end{array}$ & $\begin{array}{c}0.19 \\
(0.00)^{\mathrm{d}}\end{array}$ & $\begin{array}{l}0.29 \\
(0.01)^{\mathrm{bc}}\end{array}$ & $\begin{array}{c}0.26 \\
(0.02)^{\mathrm{c}}\end{array}$ & $\begin{array}{c}0.29 \\
(0.00)^{\mathrm{bc}}\end{array}$ & $\begin{array}{c}0.36 \\
(0.01)^{\mathrm{a}}\end{array}$ & $\begin{array}{c}0.39 \\
(0.01)^{\mathrm{a}}\end{array}$ & $\begin{array}{c}0.32 \\
(0.01)^{\mathrm{bc}}\end{array}$ & $\begin{array}{c}0.37 \\
(0.01)^{\mathrm{a}}\end{array}$ \\
\hline Galactose & $\begin{array}{c}0.45 \\
(0.01)^{\mathrm{g}}\end{array}$ & $\begin{array}{c}0.46 \\
(0.04)^{\mathrm{g}}\end{array}$ & $\begin{array}{c}0.48 \\
(0.01)^{\mathrm{g}}\end{array}$ & $\begin{array}{l}0.70 \\
(0.01)^{\mathrm{e}}\end{array}$ & $\begin{array}{c}0.58 \\
(0.01)^{\mathrm{f}}\end{array}$ & $\begin{array}{l}0.76 \\
(0.01)^{\mathrm{d}}\end{array}$ & $\begin{array}{c}0.82 \\
(0.02)^{\mathrm{c}}\end{array}$ & $\begin{array}{l}0.90 \\
(0.01)^{\mathrm{b}}\end{array}$ & $\begin{array}{c}0.97 \\
(0.02)^{\mathrm{a}}\end{array}$ & $\begin{array}{c}0.89 \\
(0.01)^{\mathrm{b}}\end{array}$ \\
\hline Lactic acid & $\begin{array}{c}0 \\
(0)^{\mathrm{h}}\end{array}$ & $\begin{array}{c}0 \\
(0)^{\mathrm{h}}\end{array}$ & $\begin{array}{c}1.82 \\
(0.04)^{\mathrm{g}}\end{array}$ & $\begin{array}{l}5.09 \\
(0.05)^{\mathrm{f}}\end{array}$ & $\begin{array}{c}5.80 \\
(0.12)^{\mathrm{e}}\end{array}$ & $\begin{array}{l}7.38 \\
(0.13)^{\mathrm{d}}\end{array}$ & $\begin{array}{c}8.04 \\
(0.09)^{\mathrm{c}}\end{array}$ & $\begin{array}{c}8.368 \\
(0.10)^{b c}\end{array}$ & $\begin{array}{l}8.48 \\
(0.34)^{\mathrm{b}}\end{array}$ & $\begin{array}{c}9.54 \\
(0.14)^{\mathrm{a}}\end{array}$ \\
\hline Acetic acid & $\begin{array}{l}0 \\
(0)^{\mathrm{f}}\end{array}$ & $\begin{array}{c}0 \\
(0)^{\mathrm{f}}\end{array}$ & $\begin{array}{c}0 \\
(0)^{\mathrm{f}}\end{array}$ & $\begin{array}{c}0.87 \\
(0.01)^{\mathrm{e}}\end{array}$ & $\begin{array}{c}0.91 \\
(0.02)^{\mathrm{de}}\end{array}$ & $\begin{array}{c}0.93 \\
(0.04)^{\mathrm{d}}\end{array}$ & $\begin{array}{c}1.02 \\
(0.01)^{\mathrm{c}}\end{array}$ & $\begin{array}{l}1.06 \\
(0.02)^{b c}\end{array}$ & $\begin{array}{c}1.08 \\
(0.02)^{\mathrm{b}}\end{array}$ & $\begin{array}{c}1.16 \\
(0.02)^{\mathrm{a}}\end{array}$ \\
\hline Butyric acid & $\begin{array}{l}0 \\
(0)^{\mathrm{f}}\end{array}$ & $\begin{array}{l}0 \\
(0)^{\mathrm{f}}\end{array}$ & $\begin{array}{l}0 \\
(0)^{\mathrm{f}}\end{array}$ & $\begin{array}{c}0.16 \\
(0.04)^{\mathrm{e}}\end{array}$ & $\begin{array}{c}0.16 \\
(0.00)^{\mathrm{e}}\end{array}$ & $\begin{array}{c}0.22 \\
(0.01)^{\mathrm{d}}\end{array}$ & $\begin{array}{l}0.30 \\
(0.01)^{\mathrm{c}}\end{array}$ & $\begin{array}{c}0.43 \\
(0.01)^{\mathrm{b}}\end{array}$ & $\begin{array}{c}0.46 \\
(0.02)^{\mathrm{b}}\end{array}$ & $\begin{array}{c}0.63 \\
(0.00)^{\mathrm{a}}\end{array}$ \\
\hline Propionic acid & $\begin{array}{c}0.42 \\
(0.03)^{\mathrm{d}}\end{array}$ & $\begin{array}{c}0.44 \\
(0.02)^{\mathrm{d}}\end{array}$ & $\begin{array}{c}0.80 \\
(0.03)^{\mathrm{c}}\end{array}$ & $\begin{array}{c}1.09 \\
(0.02)^{\mathrm{a}}\end{array}$ & $\begin{array}{c}1.11 \\
(0.01)^{\mathrm{a}}\end{array}$ & $\begin{array}{c}1.13 \\
(0.02)^{\mathrm{a}}\end{array}$ & $\begin{array}{c}1.13 \\
(0.01)^{\mathrm{a}}\end{array}$ & $\begin{array}{c}1.09 \\
(0.01)^{\mathrm{a}}\end{array}$ & $\begin{array}{c}1.09 \\
(0.02)^{\mathrm{a}}\end{array}$ & $\begin{array}{c}0.96 \\
(0.02)^{b}\end{array}$ \\
\hline Citric acid & $\begin{array}{c}4.29 \\
(0.04)^{\mathrm{a}}\end{array}$ & $\begin{array}{c}4.18 \\
(0.41)^{\mathrm{a}}\end{array}$ & $\begin{array}{l}4.05 \\
(0.62)^{\mathrm{a}}\end{array}$ & $\begin{array}{c}2.73 \\
(0.60)^{\mathrm{b}}\end{array}$ & $\begin{array}{l}3.03 \\
(0.07)^{\mathrm{b}}\end{array}$ & $\begin{array}{l}2.68 \\
(0.14)^{b}\end{array}$ & $\begin{array}{l}2.90 \\
(0.04)^{\mathrm{b}}\end{array}$ & $\begin{array}{l}2.70 \\
(0.10)^{\mathrm{b}}\end{array}$ & $\begin{array}{l}2.78 \\
(0.10)^{\mathrm{b}}\end{array}$ & $\begin{array}{l}2.89 \\
(0.04)^{\mathrm{b}}\end{array}$ \\
\hline Ethanol & $\begin{array}{c}0 \\
(0)^{\mathrm{f}}\end{array}$ & $\begin{array}{c}0 \\
(0)^{\mathrm{f}}\end{array}$ & $\begin{array}{c}0 \\
(0)^{\mathrm{f}}\end{array}$ & $\begin{array}{c}0.07 \\
(0.02)^{\mathrm{ef}}\end{array}$ & $\begin{array}{c}0.14 \\
(0.04)^{\mathrm{e}}\end{array}$ & $\begin{array}{c}0.32 \\
(0.04)^{\mathrm{d}}\end{array}$ & $\begin{array}{c}0.45 \\
(0.03)^{\mathrm{c}}\end{array}$ & $\begin{array}{c}0.89 \\
(0.03)^{\mathrm{b}}\end{array}$ & $\begin{array}{c}0.87 \\
(0.03)^{\mathrm{b}}\end{array}$ & $\begin{array}{c}1.36 \\
(0.06)^{\mathrm{a}}\end{array}$ \\
\hline $\mathrm{pH}$ & $\begin{array}{c}6.55 \\
(0.01)^{\mathrm{a}}\end{array}$ & $\begin{array}{c}6.55 \\
(0.01)^{\mathrm{a}}\end{array}$ & $\begin{array}{c}6.09 \\
(0.01)^{\mathrm{b}}\end{array}$ & $\begin{array}{c}5.64 \\
(0.02)^{\mathrm{c}}\end{array}$ & $\begin{array}{c}5.32 \\
(0.01)^{\mathrm{d}}\end{array}$ & $\begin{array}{c}4.85 \\
(0.01)^{\mathrm{e}}\end{array}$ & $\begin{array}{l}4.75 \\
(0.01)^{\mathrm{f}}\end{array}$ & $\begin{array}{c}4.53 \\
(0.01)^{\mathrm{g}}\end{array}$ & $\begin{array}{c}4.51 \\
(0.01)^{\mathrm{h}}\end{array}$ & $\begin{array}{c}4.31 \\
(0.00)^{\mathrm{i}}\end{array}$ \\
\hline
\end{tabular}

\footnotetext{
${ }^{\mathrm{a}-\mathrm{i}}$ Values within a row with different superscript letters are significantly different $(P<0.05)$, as determined by the Tukey test.

${ }^{1}$ Data represent means (SD in parentheses) based on 3 replicates of kefir samples.
} 
this study, the RT-PCR-DGGE analysis demonstrated that all microorganisms were active during fermentation and storage, with the exception of Lb. kefiri, only present in the kefir grain. It seems that $L b$. kefiri was present but not active in the kefir beverage, participating in the composition of the grain with the likely function of balancing the microflora and ecology of the grains. Meanwhile, Lb. kefiranofaciens was shown to be the most predominant and active microorganism in the kefir beverage, a result also reported by Magalhães et al. (2010b).

Lactobacillus kefiranofaciens, Lb. parakefiri, and $S$. cerevisiae were shown to be active microorganisms in the studied Brazilian kefir beverage. Additionally, $L b$. lactis ssp. lactis, Lb. lactis ssp. cremoris, L. mesenteroides, A. lovaniensis, and $S$. cerevisiae also make up the cultivable microbiota. Several researchers have studied the composition of the microbiota in kefir grain by culture-dependent (Simova et al., 2002; Guzel-Seydim et al., 2005; Witthuhn et al., 2005; da Cruz Pedrozo Miguel et al., 2010) and -independent techniques (Chen et al., 2008; Zhou et al., 2009; da Cruz Pedrozo Miguel et al., 2010; Magalhães et al., 2010b; Kesmen and Kacmaz, 2011; Leite et al., 2012), but little is known about microbiota of kefir beverage. Magalhães et al. (2011b) isolated a variety of Lactobacillus species in appropriate culture media, as well as A. lovaniensis and non-lactose- and lactose-fermenting yeast during the fermentation of a Brazilian milk kefir sample. On the other hand, the microorganisms found in this study by the PCR-DGGE analysis were similar to those reported by Magalhães et al. (2010b) in a Brazilian kefir grain and kefir manufactured with different dairy substrates by culture-independent methods.

Comparing the results obtained in this study by both culture-dependent and culture-independent methods, we observed correlations for the yeast community, whereas no correlation was found for the bacterial community. With regard to the yeast community, the plate counts and identification of isolated strains correlated well with the PCR-DGGE and RT-PCR-DGGE profiles. Predominant S. cerevisiae bands were obtained in both DGGE fingerprints and isolated by the culturing method throughout the analyzed period. Reversetranscription PCR-DGGE profiles confirm the viability and predominance of this non-lactose-fermenting yeast in the community during the studied kefir beverage fermentation and storage.

On the other hand, no specific DGGE signals for Lactococcus spp., Leuconostoc spp., and AAB were found at the DNA or RNA levels, whereas there was a presumptive count for these microorganism groups and, in fact, they were isolated during culture. Lactobacillus kefiranofaciens was the dominant organism in the kefir samples by PCR-DGGE analysis, but was not isolated on the selective media. This most likely occurred due to the relatively small number of strains evaluated $(92$ total), which could not reveal an overview of the community, and (or) the culture media used in the study was not suitable, as perhaps the lack of supplements and nutrients necessary for the growth of these species in the culture media may have influenced these results (Kesmen and Kacmaz, 2011).

These results have already been noted by other authors (Flórez and Mayo, 2006; Chen et al., 2008; Kesmen and Kacmaz, 2011) using polyphasic approaches in studies regarding food microbial ecology. Some possibilities include, perhaps, the fact that the cell numbers of some LAB species were lower than the detection limit of PCR-DGGE (Cocolin et al., 2004) or species from more abundant populations in the mixture might give greater amounts of template DNA that compete for primers during the amplification reaction, resulting in the formation of PCR products only for the dominant species (Prakitchaiwattana et al., 2004; Jany and Barbier, 2008).

Moreover, we observed that some culture media were not selective as previously discussed in other studies (Randazzo et al., 2002; Witthuhn et al., 2005; Chen et al., 2008). Those authors used strategies to adjust the media or conditions for cultivation to favor the growth of expected microorganisms. Without this, their presence would be overlooked. Therefore, we agree that cultivation methods may over- or underestimate the microbial diversity, not always being representative of this complex ecosystem. Thus, the application of a polyphasic approach, as performed in the present study, using culture-dependent and culture-independent methods, may be worthwhile to obtain a more accurate view of the structure of the microbial community (Flórez and Mayo, 2006; Chen et al., 2008; Kesmen and Kacmaz, 2011).

Considering the chemical composition of the kefir beverage, the lactose reduction was expected, because lactose is readily hydrolyzed to glucose and galactose by Lactococcus spp., Lactobacillus spp., and by some strains of Kluyveromyces spp. (Güzel-Seydim et al., 2000a; Grønnevik et al., 2011; Magalhães et al., 2011a). The most frequently isolated bacteria from kefir in previous reports, and also found in the present study, were both homofermentative and heterofermentative bacteria, such as Lactobacillus, Lactococcus, Leuconostoc, and Acetobacter (Güzel-Seydim et al., 2000a; Grønnevik et al., 2011; Magalhães et al., 2011b). Both pathways are used by these bacteria and the fermentative process is characterized by the accumulation of organic acids and decreases in $\mathrm{pH}$ values.

Acetic acid is an intermediary in citrate metabolism. It can be produced by the oxidation of ethanol and it is 
another end product of the heterofermentative lactose metabolism (Paramithiotis et al., 2006; Grønnevik et al., 2011), formed probably by heterofermentative LAB and AAB. González de Llano et al. (1996) also found butyric and propionic acids when evaluating the activity of Lactococcus spp. and Leuconostoc spp. cultures in milk fermentation and attributed the increase in butyric and propionic acid concentrations to nonspecific esterase activities by lactococcal strains.

Ethanol production increased during the fermentation and storage processes, and the values found were lower than those quantified previously in a Brazilian kefir beverage by HPLC (Magalhães et al., 2011a,b). Ethanol production is typically derived from yeast metabolism, such as from $S$. cerevisiae identified in this study. However, heterofermentative bacteria such as Lactobacillus kefiri and Leuconostoc spp. are also capable of producing ethanol (Güzel-Seydim et al., 2000a; Magalhães et al., 2011a), as they show alcohol dehydrogenase activity, which is an enzyme capable of converting acetaldehyde to ethanol. Part of the ethanol content may also be converted to acetic acid by heterofermentative bacteria (Magalhães et al., 2010a), such as bacteria belonging to the genus Acetobacter also isolated in our study.

The produced organic acids contribute not only to the flavor and aroma of fermented dairy products but also to their preservation (Güzel-Seydim et al., 2000a; Magalhães et al., 2011a). Moreover, the end products of yeast fermentation, ethanol, and $\mathrm{CO}_{2}$, are critical in producing the exotic refreshing flavor and yeasty aroma of authentic kefir (Güzel-Seydim et al., 2000a,b). Differences between the organic acid contents found in the present study and other reports involving kefir fermentation and storage (Güzel-Seydim, et al., 2000a,b; Grønnevik et al., 2011; Magalhães et al., 2010b, 2011b) might be due to the variations in the ratio of inoculated kefir grains and the microorganism species present in the different kefir grains (Güzel-Seydim et al., 2000a; Irigoyen et al., 2005).

\section{CONCLUSIONS}

The bacterial community detected through the use of the culture-dependent method were not the same as those detected by the culture-independent method. Therefore, these techniques should be combined to obtain a more complete view of the microbial ecosystem and the succession of their predominant populations during the fermentation and storage processes of a sample of kefir beverage. Denaturing gel gradient electrophoresis analysis of microbial DNA and RNA was important to confirm that the predominant microbial community detected at the DNA level was metaboli- cally active during all production and storage stages of the beverage, with the exception of Lb. kefiri. The identification of microorganisms involved in these processes, as well as their generated metabolites, mainly acetic and lactic acids, exerts a strong influence in the unique sensory characteristics of the end product. This may serve as a basis for the future industrial production of this beverage in Brazil.

\section{ACKNOWLEDGMENTS}

The authors acknowledge financial support for this project from Fundação de Amparo à Pesquisa do Estado do Rio de Janeiro (FAPERJ, Rio de Janeiro, Brazil), Conselho Nacional de Desenvolvimento Científico e Tecnológico (CNPq, Brasília, Brazil), and Coordenação de Aperfeiçoamento de Pessoal de Nível Superior (CAPES, Brasília, Brazil).

\section{REFERENCES}

Carr, J. G., and S. M. Passmore. 1979. Methods for identifying acetic acid bacteria. Pages 33-47 in Identification Methods for Microbiologists. F. A. Skinner and D. W. Lovelock, ed. Academic Press, London, UK.

Chen, H.-C., S.-Y. Wang, and M.-J. Chen. 2008. Microbiological study of lactic acid bacteria in kefir grains by culture-dependent and culture-independent methods. Food Microbiol. 25:492-501.

Cocolin, L., D. Aggio, M. Manzano, C. Cantoni, and G. Comi. 2002. An application of PCR-DGGE analysis to profile the yeast populations in raw milk. Int. Dairy J. 12:407-411.

Cocolin, L., K. Rantsiou, L. Iacumin, R. Urso, C. Cantoni, and G. Comi. 2004. Study of the ecology of fresh sausages and characterization of populations of lactic acid bacteria by molecular methods. Appl. Environ. Microbiol. 70:1883-1894.

da Cruz Pedrozo Miguel, M. G., P. G. Cardoso, L. de Assis Lago, and R. F. Schwan. 2010. Diversity of bacteria present in milk kefir grains using culture-dependent and culture-independent methods. Food Res. Int. 43:1523-1528.

Del Aguila, E. M., J. T. Silva, and V. M. F. Paschoalin. 2003. Expression of the yeast calcineurin subunits CNA1 and CNA2 during growth and hyper-osmotic stress. FEMS Microbiol. Lett. 221:197-202.

Dolci, P., V. Alessandria, K. Rantsiou, M. Bertolino, and L. Cocolin. 2010. Microbial diversity, dynamics and activity throughout manufacturing and ripening of Castelmagno PDO cheese. Int. J. Food Microbiol. 143:71-75.

Falentin, H., N. Henaff, P. Le Bivic, S.-M. Deutsch, S. Parayre, R. Richoux, D. Sohier, A. Thierry, S. Lortal, and F. Postollec. 2012. Reverse transcription quantitative PCR revealed persistency of thermophilic lactic acid bacteria metabolic activity until the end of the ripening of Emmental cheese. Food Microbiol. 29:132-140.

FAO/WHO (Food and Agriculture Organization of the United Nations/World Health Organization). 2003. Codex Standard for Fermented Milks. Codex Stan 243-2003. 2nd ed. FAO/WHO, Rome, Italy.

Farnworth, E. R. 2005. Kefir-A complex probiotic. Food Sci. Technol. Bull. 2:1-17.

Farnworth, E. R., and I. Mainville. 2008. Kefir-A fermented milk product. Pages 89-127 in Handbook of Fermented Functional Foods. 2nd ed. E. R. Farnworth, ed. CRC Press Taylor \& Francis Group, Boca Raton, FL; London, UK; and New York, NY.

Flórez, A. B., and B. Mayo. 2006. PCR-DGGE as a tool for characterizing dominant microbial populations in the Spanish blue-veined Cabrales cheese. Int. Dairy J. 16:1205-1210. 
García Fontán, M. C., S. Martínez, I. Franco, and J. Carballo. 2006. Microbiological and chemical changes during the manufacture of Kefir made from cows' milk, using a commercial starter culture. Int. Dairy J. 16:762-767.

Garrote, G. L., A. G. Abraham, and G. L. De Antoni. 2010. Microbial interactions in kefir: A natural probiotic drink. Pages 327-340 in Biotechnology of Lactic Acid Bacteria: Novel Applications. F. Mozzi, R. R. Raya, and G. M. Vignolo, ed. Blackwell Publishing, Ames, IA.

González de Llano, D., A. Rodriguez, and P. Cuesta. 1996. Effect of lactic starter cultures on the organic acid composition of milk and cheese during ripening-Analysis by HPLC. J. Appl. Microbiol. 80:570-576.

Grønnevik, H., M. Falstad, and J. A. Narvhus. 2011. Microbiological and chemical properties of Norwegian kefir during storage. Int. Dairy J. 21:601-606.

Guzel-Seydim, Z., J. T. Wyffels, A. C. Seydim, and A. K. Greene. 2005. Turkish kefir and kefir grains: Microbial enumeration and electron microscopic observation. Int. J. Dairy Technol. 58:25-29.

Güzel-Seydim, Z. B., A. C. Seydim, A. K. Greene, and A. B. Bodine. 2000a. Determination of organic acids and volatile flavor substances in kefir during fermentation. J. Food Compost. Anal. 13:35-43.

Guzel-Seydim, Z. B., A. C. Seydim, A. K. Greene, and A. B. Bodine. 2000b. Organic acid and volatile flavor components evolved during refrigerated storage of kefir. J. Dairy Sci. 83:275-277.

Irigoyen, A., I. Arana, M. Castiella, P. Torre, and F. C. Ibáñez. 2005. Microbiological, physicochemical, and sensory characteristics of kefir during storage. Food Chem. 90:613-620.

Jany, J. L., and G. Barbier. 2008. Culture-independent methods for identifying microbial communities in cheese. Food Microbiol. 25:839-848.

Kesmen, Z., and N. Kacmaz. 2011. Determination of lactic microflora of kefir grains and kefir beverage by using culture-dependent and culture-independent methods. J. Food Sci. 76:M276-M283.

Leite, A. M. O., B. Mayo, C. T. C. C. Rachid, R. S. Peixoto, J. T. Silva, V. M. F. Paschoalin, and S. Delgado. 2012. Assessment of the microbial diversity of Brazilian kefir grains by PCR-DGGE and pyrosequencing analysis. Food Microbiol. 31:215-221.

Magalhães, K. T., D. R. Dias, G. V. de Melo Pereira, J. M. Oliveira, L. Domingues, J. A. Teixeira, J. B. de Almeida e Silva, and R. F. Schwan. 2011a. Chemical composition and sensory analysis of cheese whey-based beverages using kefir grains as starter culture. Int. J. Food Sci. Technol. 46:871-878.

Magalhães, K. T., G. V. de Melo Pereira, C. R. Campos, G. Dragone, and R. F. Schwan. 2011b. Brazilian kefir: Structure, microbial communities and chemical composition. Braz. J. Microbiol. 42:693-702.

Magalhães, K. T., G. V. de M. Pereira, D. R. Dias, and R. F. Schwan. 2010a. Microbial communities and chemical changes during fermentation of sugary Brazilian kefir. World J. Microbiol. Biotechnol. 26:1241-1250.

Magalhães, K. T., M. A. Pereira, A. Nicolau, G. Dragone, L. Domingues, J. A. Teixeira, J. B. de Almeida Silva, and R. F.
Schwan. 2010b. Production of fermented cheese whey-based beverage using kefir grains as starter culture: Evaluation of morphological and microbial variations. Bioresour. Technol. 101:8843-8850.

Mainville, I., N. Robert, B. Lee, and E. R. Farnworth. 2006. Polyphasic characterization of the lactic acid bacteria in kefir. Syst. Appl. Microbiol. 29:59-68.

Muyzer, G., E. C. de Waal, and A. G. Uitterlinden. 1993. Profiling of complex microbial populations by denaturing gradient gel electrophoresis analysis of polymerase chain reaction-amplified genes coding for 16S rRNA. Appl. Environ. Microbiol. 59:695-700.

Naumova, E., Y. Ivannikova, and G. Naumov. 2005. Genetic differentiation of the sherry yeasts Saccharomyces cerevisiae. Appl. Biochem. Microbiol. 41:578-582.

Not, F., J. del Campo, V. Balagué, C. de Vargas, and R. Massana. 2009. New insights into the diversity of marine picoeukaryotes. PLOS ONE 4:e7143.

Öner, Z., A. G. Karahan, and M. L. Çakmakçı. 2010. Effects of different milk types and starter cultures on kefir. Gida 35:177-182.

Paramithiotis, S., S. Gioulatos, E. Tsakalidou, and G. Kalantzopoulos. 2006. Interactions between Saccharomyces cerevisiae and lactic acid bacteria in sourdough. Process Biochem. 41:2429-2433.

Plessas, S., A. Alexopoulos, C. Voidarou, E. Stavropoulou, and E. Bezirtzoglou. 2011. Microbial ecology and quality assurance in food fermentation systems. The case of kefir grains application. Anaerobe 17:483-485.

Prakitchaiwattana, C. J., G. H. Fleet, and G. M. Heard. 2004. Application and evaluation of denaturing gradient gel electrophoresis to analyse the yeast ecology of wine grapes. FEMS Yeast Res. 4:865-877.

Randazzo, C. L., S. Torriani, A. D. L. Akkermans, W. M. de Vos, and E. E. Vaughan. 2002. Diversity, dynamics, and activity of bacterial communities during production of an artisanal Sicilian cheese as evaluated by $16 \mathrm{~S}$ rRNA analysis. Appl. Environ. Microbiol. 68:1882-1892.

Rantsiou, K., R. Urso, P. Dolci, G. Comi, and L. Cocolin. 2008. Microflora of Feta cheese from four Greek manufacturers. Int. J. Food Microbiol. 126:36-42.

Simova, E., D. Beshkova, A. Angelov, T. Hristozova, G. Frengova, and Z. Spasov. 2002. Lactic acid bacteria and yeasts in kefir grains and kefir made from them. J. Ind. Microbiol. Biotechnol. 28:1-6.

Tamime, A. Y., M. Wszolek, R. Božanić, and B. Özer. 2011. Popular ovine and caprine fermented milks. Small Rumin. Res. 101:2-16.

Wang, X., S. Haruta, P. Wang, M. Ishii, Y. Igarashi, and Z. Cui. 2006. Diversity of a stable enrichment culture which is useful for silage inoculant and its succession in alfalfa silage. FEMS Microbiol. Ecol. 57:106-115.

Witthuhn, R. C., T. Schoeman, and T. J. Britz. 2005. Characterization of the microbial population at different stages of kefir production and kefir grain mass cultivation. Int. Dairy J. 15:383-389.

Zhou, J., X. Liu, H. Jiang, and M. Dong. 2009. Analysis of the microflora in Tibetan kefir grains using denaturing gradient gel electrophoresis. Food Microbiol. 26:770-775. 